\title{
Clustering Model to Measuring Level of Game Addiction
}

\author{
Anastasya Latubessy ${ }^{1}$, Ratih Nindyasari ${ }^{2}$, Alif Catur Murti ${ }^{3}$, Aditya Akbar Riadi ${ }^{4}$, Tutik \\ Khotimah $^{5}$ \\ \{anastasya.latubessy@umk.ac.id ${ }^{1}$, ratih.nindyasari@umk.ac.id², alif.catur@umk.ac.id ${ }^{3}$ \} \\ Universitas Muria Kudus, Kampus UMK Street, Gondang manis, Bae, Kudus, Central Java, \\ Indonesia, $59327^{12345}$
}

\begin{abstract}
World Health Organization (WHO) has issued a statement that addiction to the game is one of the mental disorders. Playing games favored by various age groups. Adults and children love to play games. Excessive game play patterns can lead to addiction to games. Actually, the rate of addiction to games can be measured. One way of measuring the level of game addiction is to classify the symptoms of this type of game addiction behavior. There are six types of game addiction behavior that have been obtained from previous research. Those symptoms can be grouped using one of the clustering methods. This study uses K-Means Clustering to categorize the rate of game addiction.
\end{abstract}

Keywords: addiction, clustering, game.

\section{Introduction}

Game addiction is one type of psychiatric disorder. This is reinforced by the WHO statement. Excessive to playing game can also affect the learning process of children in school. The study mentions, there is a negative correlation between playing games with children's learning. There is a relationship between game addictions with liveliness of students in the learning process. The relationship that occurs is a negative correlation where, the higher the game addiction then the students activity in the learning process decreases[1]. Other studies have shown that online games also affect the learning achievement of adolescents. The study states that teenagers prefer to love online games rather than lessons [2]. Game addiction also affects early adult social skills. Early adult gamers have been addicted to the game for making online games an escape from the problems they are facing [3]. This leads to a reduction in social interaction based on the Tennessee Self Concept Scale (TSCS)[4]. Play online games serve as a place to find fun, get a new world in playing online games, and various emotional outbursts can be felt as an interesting when playing online games[5]. It was found that Internet/ digital game addicted individuals formed close friend groups and interacted with other Internet/ digital game addicted individuals and that the non-addicted individuals formed groups with other non-addicts[6].

Based on this, research has been done to look for symptoms of game addiction. There are six types of addiction game such as, Salience, Euphoria, Conflict, Tolerance, Withdrawal, Relapse and Reinstatement. Previous research has modeled for identification of game addiction rates. Models created using backward chaining method[7]. Testing the validity of the model is done by testing the closeness of the agreement between the model analysis and expert analysis,

ICCSET 2018, October 25-26, Kudus, Indonesia

Copyright () 2018 EAI

DOI 10.4108/eai.24-10-2018.2280618 
resulting in a value of 0.78 which means having a strong agreement[8]. Different from previous research, this study tried to categorize the level of game addiction based on the symptoms using K Means Clustering. This study will identify children based on their play patterns. This pattern then becomes the basis for determining the level of child's game addiction.

\section{Research Method}

This research using clustering method that is done in this research is as follows. The first thing to do is to determine the number of clusters. After that, calculate the Central value for each cluster. After obtaining the middle value of each cluster, calculate the distance of each data to each centroid using Euclidean distance. Compare results for each cluster. The smallest increment will be a member of the cluster. The arrangement of the algorithm used is shown in the figure 1 .

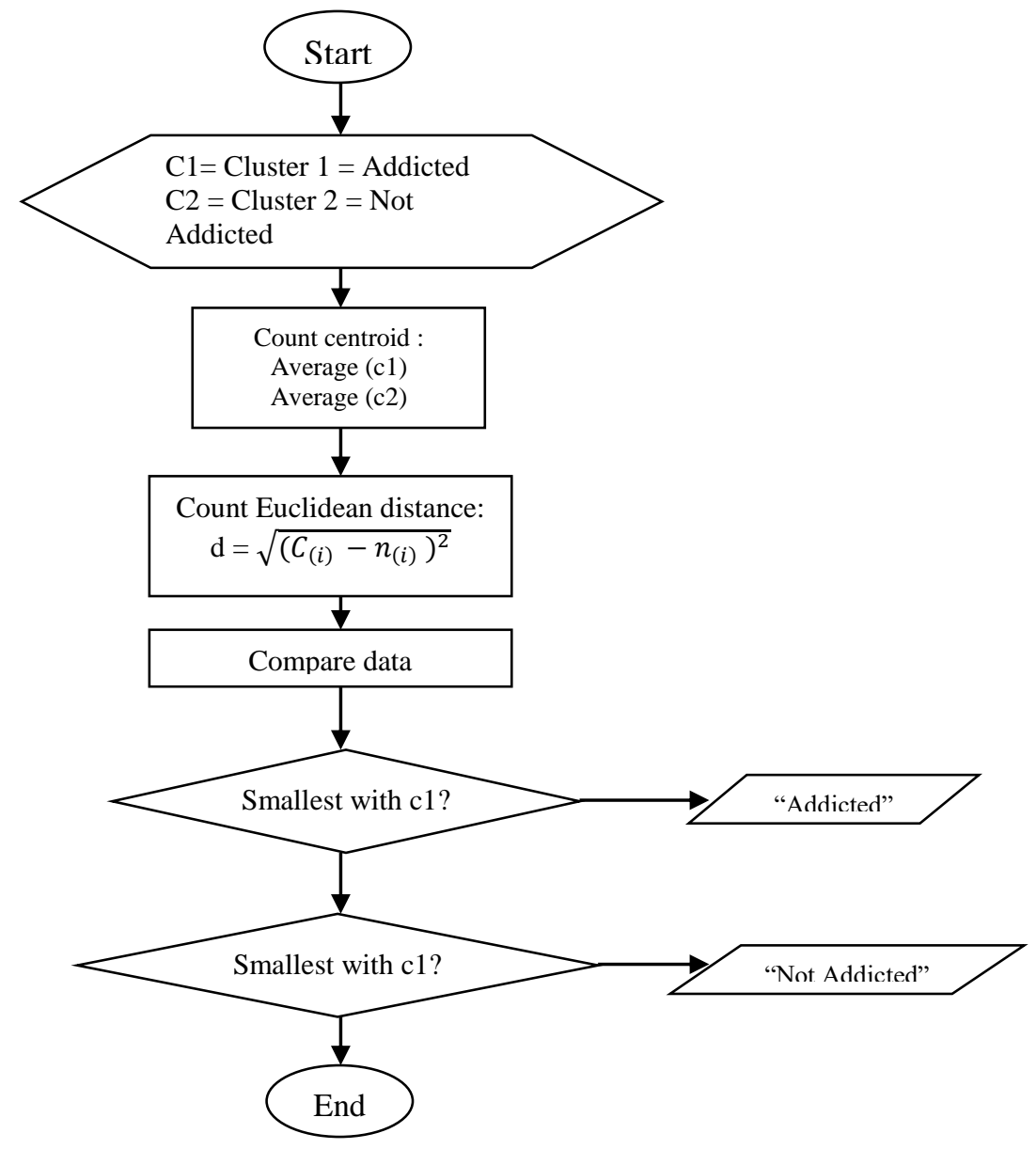


Fig. 1. K Means Clustering Algorithm for Game Addiction Identification Case.

$\mathrm{K}$ Means Clustering is one of the most commonly used clustering models in grouping. This model was once used to determine the nutritional status of children[9]. The K Means model has also been used to categorize acute and non-acute illnesses[10].

\section{Results and Discussion}

This study used ten data with the distribution of age between nine to twelve years old. The results of the identification of the ten child data produced the results as shown in Table 1. There are six types of game addictions behavior such as, Salience, Euphoria, Conflict, Tolerance, Withdrawal, Relapse and Reinstatement. The results show varying number of types. The results of identification produce data with one type until six types of game addiction behavior.

Table 1. Result of identification Data Used.

\begin{tabular}{ccc}
\hline Sample & Age (years) & Indicated Types of Game Addiction Behavior \\
\hline Data 1 & 9 & 2 types \\
Data 2 & 9 & 3 types \\
Data 3 & 12 & 4 types \\
Data 4 & 10 & 5 types \\
Data 5 & 11 & 1 types \\
Data 6 & 10 & 6 types \\
Data 7 & 11 & 6 types \\
Data 8 & 10 & 4 types \\
Data 9 & 11 & 3 types \\
Data 10 & 12 & 2 types \\
\hline
\end{tabular}

\subsection{K Means Modeling}

The first step of $K$ Means modeling is calculating the value of centroid using the average formula. Someone is said to be addicted to games when they have three types of game addiction behavior. Calculation of centroid value is obtained by the following equation. $\mathrm{C} 1$ is the first centroid used as a cluster for game addiction, while C2 is the second centroid used as a cluster to not addict to the game.

$$
\begin{aligned}
& C 1=\frac{3+4+5+6}{4}=4.5 \\
& C 2=\frac{1+2}{2}=1.5
\end{aligned}
$$

The value for the first centroid is 4.5 while the value for the second centroid is 1.5 . The next step is to calculate the Euclidean distance of the sample data with each centroid. Through the use of calculating distance formula, we can find the closest distance between each data with cluster. This research using Euclidean distance formula to calculate the distance. The Euclidean distance formula is shown in equation 3. 


$$
\mathrm{d}=\sqrt{\left(C_{(i)}-n_{(i)}\right)^{2}}
$$

Symbol d represents the distance, while symbol $\mathrm{n}_{(\mathrm{i})}$ is the sample data from one data to a number of sample data. By calculating the distance between each data to the centroid value, we can get a cluster membership. Membership is obtained by viewing the closest distance. The distance closest to the centroid is a member of the cluster. The calculation results are shown in Table 2.

The closest distance to the first and fifth data is with the second centroid so that the first and fifth data are the second cluster members which are classified as not addicted to the game. While the third, fourth, sixth, seventh and eighth of the smallest difference with the first centroid, it will be a member of the first cluster which is addicted to the game. Based on table 2 can be seen that the number of members $\mathrm{C} 2$ as much as two data. The result of $\mathrm{C} 1$ equals to $\mathrm{C} 2$ expressing the indication threshold with three types. According to previous research if indicated three types then it is including game addiction. Then $\mathrm{C} 1$ equals to $\mathrm{C} 2$ made into $\mathrm{C} 1$. That means only three out of ten child data samples are not addicted to the game. It needs special attention from parents and teachers.

Table 2. Result Identification of Data Used.

\begin{tabular}{ccccccccc}
\hline Data & $\mathrm{N}$ & $\mathrm{c} 1-\mathrm{n}(\mathrm{i})$ & $\mathrm{c} 2-\mathrm{n}(\mathrm{i})$ & $\mathrm{(c1-n( \textrm {i } ) ) 2}$ & $\mathrm{(c2-n( \textrm {i } ) ) 2}$ & $\begin{array}{c}\text { Euclidean } \\
\text { distances } \\
\text { DnC1 }\end{array}$ & $\begin{array}{c}\text { Euclidean } \\
\text { distances } \\
\text { DnC2 }\end{array}$ & Result \\
\hline D1 & 2 & 2,5 & $-0,5$ & 6,25 & 0,25 & 2,5 & 0,5 & $\mathrm{C} 2$ \\
D2 & 3 & 1,5 & $-1,5$ & 2,25 & 2,25 & 1,5 & 1,5 & $\mathrm{C} 1=\mathrm{C} 2$ \\
D3 & 4 & 0,5 & $-2,5$ & 0,25 & 6,25 & 0,5 & 2,5 & $\mathrm{C} 1$ \\
D4 & 5 & $-0,5$ & $-3,5$ & 0,25 & 12,25 & 0,5 & 3,5 & $\mathrm{C} 1$ \\
D5 & 1 & 3,5 & 0,5 & 12,25 & 0,25 & 3,5 & 0,5 & $\mathrm{C} 2$ \\
D6 & 6 & $-1,5$ & $-4,5$ & 2,25 & 20,25 & 1,5 & 4,5 & $\mathrm{C} 1$ \\
D7 & 6 & $-1,5$ & $-4,5$ & 2,25 & 20,25 & 1,5 & 4,5 & $\mathrm{C} 1$ \\
D8 & 4 & 0,5 & $-2,5$ & 0,25 & 6,25 & 0,5 & 2,5 & $\mathrm{C} 1$ \\
D9 & 3 & 1,5 & $-1,5$ & 2,25 & 2,25 & 1,5 & 1,5 & $\mathrm{C} 1=\mathrm{C} 2$ \\
D10 & 2 & 2,5 & $-0,5$ & 6,25 & 0,25 & 2,5 & 0,5 & $\mathrm{C} 2$ \\
\hline
\end{tabular}

\subsection{K Means Cluster Testing}

Testing of K Means Clustering model is done by comparing the results of this method with the result of the methods obtained in previous research. Previous research used a backward chaining model in the identification of game addiction rates in children. Testing with backward chaining model with manual test result by the expert yields data as shown in Table 3. Based on the results of testing the closeness of the agreement between Backward Chaining models with expert to identification of game addiction rate in children using Cohen's Kappa Coefficient method shows a strong interpretation value of 0.78 . This means the backward chaining model is appropriate for identification cases of game addiction levels as well can be used as a model in development an expert game addiction system add-ons app[8]. 
Table 3. Comparison Backward Chaining and Expert Testing[8].

\begin{tabular}{cccc}
\hline Sample & Backward Chaining & Expert Testing & Compatibility \\
\hline Data 1 & Not Addicted & Not Addicted & Yes \\
Data 2 & Addicted & Not Addicted & Not \\
Data 3 & Addicted & Addicted & Yes \\
Data 4 & Addicted & Addicted & Yes \\
Data 5 & Not Addicted & Not Addicted & Yes \\
Data 6 & Addicted & Addicted & Yes \\
Data 7 & Addicted & Addicted & Yes \\
Data 8 & Addicted & Addicted & Yes \\
Data 9 & Addicted & Addicted & Yes \\
Data 10 & Not Addicted & Not Addicted & Yes \\
\hline
\end{tabular}

Therefore, current studies compare the results obtained with the $\mathrm{K}$ Means model with backward chaining model. The comparison results of both models are $100 \%$ as shown in Table 4. With $100 \%$ match results it can be concluded that $\mathrm{K}$ Means Clustering model is also suitable for the case of game addiction identification.

Table 4. Comparison K Means and Backward Chaining.

\begin{tabular}{cccc}
\hline Sample & Backward Chaining & K Means Clustering & Compatibility \\
\hline Data 1 & Not Addicted & Not Addicted & Yes \\
Data 2 & Addicted & Addicted & Yes \\
Data 3 & Addicted & Addicted & Yes \\
Data 4 & Addicted & Addicted & Yes \\
Data 5 & Not Addicted & Not Addicted & Yes \\
Data 6 & Addicted & Addicted & Yes \\
Data 7 & Addicted & Addicted & Yes \\
Data 8 & Addicted & Addicted & Yes \\
Data 9 & Addicted & Addicted & Yes \\
Data 10 & Not Addicted & Not Addicted & Yes \\
\hline
\end{tabular}

\section{Conclusion}

Modeling has been done to identify whether a child is addicted to the game or not. The results obtained that only three children were not addicted to the game of the ten samples of data used. This research used clustering model to identify. The selected clustering model is $K$ Means Clustering. The result of identification using K Means Clustering is similar to the result of identification with backward chaining model in previous research. Which is means $K$ Means Clustering is also suitable for the game addiction identification model. 


\section{References}

[1] A. Latubessy and M. N. Ahsin, "Hubungan Antara Adiksi Game Terhadap Keaktifan Pembelajaran Anak Usia 9-11 Tahun," Simetris J. Tek. Mesin Elektro Dan Ilmu Komput., vol. 7, no. 2, pp. 687-692, 2016.

[2] T. R. Ariantoro, "Dampak Game Online Terhadap Prestasi Belajar Pelajar," J. Tek. Inform. Musirawas JUTIM, vol. 1, no. 1, 2018.

[3] S. Virlia and S. Setiadji, "Hubungan Kecanduan Game Online Dan Keterampilan Sosial Pada Pemain Game Dewasa Awal Di Jakarta BARAT," Psibernetika, vol. 9, no. 2, 2017.

[4] L. Ayu and S. Saragih, "Interaksi Sosial dan Konsep Diri dengan Kecanduan Games Online pada Dewasa Awal," Pers. J. Psikol. Indones., vol. 5, no. 02, 2016.

[5] R. Syahran, "Ketergantungan online game dan penanganannya," J. Psikol. Pendidik. Dan Konseling J. Kaji. Psikol. Pendidik. Dan Bimbing. Konseling, vol. 1, no. 1, pp. 84-92, 2015.

[6] S. Gunuc, "Peer Influence in Internet and Digital Game Addicted Adolescents: Is Internet / Digital Game Addiction Contagious?,” Int. J. High Risk Behav. Addict., vol. Inpress, no. Inpress, Oct. 2016.

[7] A. Latubessy and E. Wijayanti, "Model Identifikasi Kecanduan Game Menggunakan Backward Chaining,” Simetris J. Tek. Mesin Elektro Dan Ilmu Komput., vol. 8, no. 1, pp. 9-14, 2017.

[8] A. Latubessy and A. Jazuli, "Analisis Model Penelusuran Backward Chaining dalam Mendeteksi Tingkat Kecanduan Game pada Anak,” J. Teknol. Dan Sist. Komput., vol. 5, no. 4, p. 129, Oct. 2017. [9] W. M. P. Dhuhita, "Clustering Menggunakan Metode K-mean Untuk Menentukan Status Gizi Balita,” J. Inform. Darmajaya, vol. 15, no. 2, pp. 160-174, 2016.

[10] A. K. Wardhani, "K-Means Algorithm Implementation For Clustering Of Patients Disease In Kajen Clinic Of Pekalongan," J. Transform., vol. 14, no. 1, pp. 30-37, 2016. 